\title{
Czy pacjent powinien decydować o miejscu i sposobie leczenia
}

\author{
Should patient decide about the place and method \\ of the treatment
}

\section{Streszczenie}

W artykule przedstawiono przypadek 84-letniego chorego z uogólnioną chorobą nowotworową przebywającego od dwudziestu dwóch miesięcy pod opieką Hospicjum Domowego. Podstawowym rozpoznaniem jest rak gruczołu krokowego z mnogimi przerzutami do kości, ponadto stwierdzono u niego cukrzycę typu 2 (pacjent leczony jest doustnymi lekami przeciwcukrzycowymi), nadciśnienie tętnicze i chorobę niedokrwienną serca. Podczas sprawowania nad nim opieki hospicyjnej, pojawiła się konieczność ambulatoryjnego leczenia z powodu ropowicy stopy cukrzycowej i półpaśca I gałęzi nerwu trójdzielnego lewego z zajęciem gałki ocznej. Mężczyzna w obu sytuacjach kategorycznie odmówił hospitalizacji, amputacji podudzia oraz blokady nerwu nadoczodołowego, ponadto nie przyjął propozycji transportu na zalecane przez onkologa wlewy bisfosfonianów drogą dożylną. Chory otrzymuje według zaleceń urologa triptorelinę i deksametazon. Po blisko dwóch latach przewlekłego cewnikowania, pacjent od sześciu miesięcy oddaje mocz samoistnie. Skuteczną terapię bólu zapewniają leki opioidowe, przeciwdrgawkowe, przeciwdepresyjne, bisfosfoniany podawane drogą doustną, doraźnie niesteroidowe leki przeciwzapalne (NLPZ) i metamizol. Chory natężenie bólu według skali NRS określa na 1-2. Pacjent jest wydolny oddechowo i krążeniowo, systematycznie poddawany rehabilitacji w obrębie łóżka, siada samodzielnie do posiłków, jego stopa całkowicie się wygoiła a gałka oczna pozostała nieuszkodzona. Jest pogodny i spokojny.

Uszanowanie woli i przestrzeganie praw pacjenta, rozwaga oraz wspólne podejmowanie decyzji dotyczących licznych aspektów wielokierunkowego leczenia prawdopodobnie korzystnie wpłynęły na jego wyniki. Palliat Med Pract 2018; 12, 3: 165-171

Słowa kluczowe: uogólniona choroba nowotworowa, choroby współistniejące, prawa pacjenta, leczenie stanów nagłych

\section{Abstract}

The article describes a case of 84-year old male with disseminated malignancy, remaining under home hospice care about twenty two months. Prostatic cancer with bone metastases is patient's primary problem. Coexisting diseases are: diabetes type 2 (treated with oral medications), arterial hypertension and ischemic heart disease.

During palliative care the patient had to undergo treatment for phlegmon of diabetic foot and for herpetic zoster of the 1st branch of his left trigeminal nerve, including eye. In both situations the patient strongly refused any hospitalization, lower leg amputation or the left supraorbital nerve block. He refused also being transferred for intravenous bisphosphonates treatment recommended by the oncologist. Patient is accepting triptorelin and dexamethasone prescribed by his urologist.

Adres do korespondencji: Renata Hanna Ćwiek

Hospicjum Domowe Caritas Diecezji Łowickiej. Stacja Sochaczew

ul. Staszica 39, 96-00 Sochaczew, Polska

e-mail: rhc@vp.pl

tel.: 601470710

Palliative Medicine in Practice 2018; 12, 3, 165-171

Copyright (c) Via Medica, ISSN 2545-0425

DOI: 10.5603/PMPI.2018.0006 
Currently patient is able to urinate physiologically after having catheterizations for almost two years. His NRS pain score is 1-2 with opioids, anticonvulsants, antidepressants, oral bisphosphonates and PRN: metamizole and other NSAIDs. Cheerful and calm, with stable circulation and respiratory system, patient undergoes regular rehabilitation at the bed. He sits himself for meals. His foot is completely healed and eye not harmed.

Respecting the patient's wish and rights, appropriate consideration and making decision together, regarding numerous aspects of his multidirectional treatment, probably influenced results in a positive way. Palliat Med Pract 2018; 12, 3: 165-171

Key words: disseminated malignancy, coexisting diseases, patient's rights, treatment of emergencies

\section{Wstęp}

W polskim ustawodawstwie prawa pacjenta są zagwarantowane w Konstytucji Rzeczypospolitej Polskiej, ratyfikowanych umowach międzynarodowych i w aktach prawnych [1], zwłaszcza w ustawie z dnia 6 listopada 2008 roku o prawach pacjenta i Rzeczniku Praw Pacjenta (Dz. U. z 2017 r. poz. 1318 późn. zm.) [2]. Przedstawiony $w$ artykule pacjent $z$ rozsianym nowotworem i chorobami współistniejącymi wyraził wolę umierania w spokoju i godności. Nie zgodził się na hospitalizację i amputację podudzia z powodu ropowicy stopy cukrzycowej, sprzeciwił się również hospitalizacji i blokadzie nerwu nadoczodołowego w przebiegu półpaśca z zajęciem gałki ocznej oraz podaniu bisfosfonianów drogą dożylną w warunkach szpitalnych. Kilkakrotnie w sytuacjach wymagających hospitalizacji chory prosił o leczenie ambulatoryjne, które z powodzeniem realizowano w warunkach domowych [3].

\section{Opis przypadku}

Pacjent w wieku lat 84, w stanie ogólnym ciężkim, leżący, przewlekle cewnikowany od lipca 2015 roku, został przyjęty do domowej opieki hospicyjnej po zakończonym leczeniu przyczynowym z powodu rozpoznania raka gruczołu krokowego. Na początku choroby wystąpiło zatrzymanie moczu z towarzyszącym krwiomoczem i krwawienie z górnego odcinka przewodu pokarmowego, które leczone było zachowawczo. W wykonanej cystoskopii i TURP (transuretral resection of the prostate - przezcewkowa resekcja gruczołu krokowego) stwierdzono w pęcherzu moczowym zmiany zapalne i raka gruczołowego stercza - wskaźnik Gleasona $9(5+4)$. W badaniu tomograficznym jamy brzusznej uwidoczniono płyn obustronnie w jamach opłucnowych, torbiele w obydwu nerkach, pojedyncze powiększone węzły chłonne przyaortalne, powiększony gruczoł krokowy, pogrubiałe ściany pęcherza moczowego, zmienioną miażdżycowo aortę brzuszną z masywnymi skrzeplinami przyściennymi zwężającymi znacznie światło naczynia, zwężenie pnia trzewnego w okolicy ujścia, poszerzone jelito grube wypełnione masami kałowymi i liczne ogniska sklerotyczne o cechach przerzutów w obrębie trzonów kręgów lędźwiowych, żeber i miednicy. W scyntygrafii kości wykonanej we wrześniu 2015 roku stwierdzano mnogie przerzuty we wszystkich odcinkach kręgosłupa bez ucisku struktur nerwowych, w stawach ramiennych, w kościach miednicy z zajęciem stawów krzyżowo-biodrowych i biodrowych, w kościach udowych i w licznych żebrach oraz prawdopodobnie w kościach pokrywy czaszki.

Chorego zakwalifikowano do leczenia hormonalnego oraz do leczenia kwasem zoledronowym, który otrzymał dwukrotnie - po czym nie wyrażał zgody na transport do szpitala, aby kontynuować podawanie leku drogą dożylną. Po zakończeniu antybiotykoterapii i przetoczeniu koncentratu krwinek czerwonych w październiku 2015 roku, chory był wydolny oddechowo i krążeniowo. W wykonanym RTG klatki piersiowej stwierdzono poszerzenie aorty wstępującej, zmiany miąższowe i naciekowe w płucu prawym oraz na poziomie wnęki płuca lewego. Wśród nacieków i zmian miąższowych stwierdzono zmiany guzkowe oraz przerzuty w łopatkach. W listopadzie 2015 roku opracowano chirurgicznie stopę cukrzycową i skierowano chorego do domowej opieki paliatywnej (hospicjum domowego).

Mężczyzna skarżył się na uogólnione dolegliwości bólowe, które oceniał na 7 w skali NRS (numerical rating scale: 11-stopniowa skala numeryczna oceny natężenia bólu, od 0 - brak bólu, do 10 - ból najsilniejszy).

Mimo że stwierdzono u niego cukrzycę II typu i leczono ją metforminą i tolbutamidem, nie wyrażał zgody na włączenie insuliny. Poziomy glikemii wynosiły 100-200 mg\%. Lewą stopę cukrzycową leczył początkowo ambulatoryjnie poza miejscem zamieszkania, później ze względu na uciążliwość transportu, nie wyrażał zgody na leczenie specjalistyczne, prosząc 
o jego kontynuację w warunkach domowych. Stopniowo, pomimo stosowania zaleceń chirurga naczyniowego: opatrunków z oktenidyny z fenoksyetanolem i kontynuacji leczenia ciprofloksacyną podawaną drogą doustną, zmiany zapalne ulegały nasileniu.

Od początku objęcia chorego opieką paliatywną włączono do leczenia enoksaparynę w dawce $20 \mathrm{mg}$ na dobę. $Z$ wymazu z rany uzyskano patogen oporny na ciprofloksacynę - Aeromonas aerogenes, wrażliwy na sulfametoksazol/trimetoprim, który podawano drogą doustną przez $14 \mathrm{dni}$, a miejscowo na owrzodzenie stosowano gentamycynę na zmianę z metronidazolem. W 14. dobie obserwacji stwierdzono w badaniach laboratoryjnych ciężką niedokrwistość mikrocytarną z poziomem hemoglobiny $6,2 \mathrm{~g} / \mathrm{dl}$, bez klinicznych cech krwawienia z przewodu pokarmowego. Chory wyraził zgodę na hospitalizację i przetoczenie koncentratu krwinek czerwonych. Jego stan ogólny uległ poprawie, ale niestety stopa była w coraz gorszym stanie. Dodatkowo, pacjent wymagał leczenia flukonazolem podawanym drogą doustną przez $14 \mathrm{dni}$ z powodu grzybicy jamy ustnej.

Po miesiącu obserwacji, zgodnie z zaleceniami urologa, zaistniała konieczność włączenia deksametazonu w dawce $1 \mathrm{mg}$ na dobę drogą doustną i kontynuacji leczenia triptoreliną $w$ dawce $11,25 \mathrm{mg}$ podawanej, co 90 dni drogą domięśniową. Stwierdzono wówczas zbiorniki cuchnącej ropy drążące do podeszwowej okolicy śródstopia. Bardzo delikatnie płukano je jodopowidonem na zmianę z metronidazolem, a na owrzodzenie w okolicy kostki przyśrodkowej stosowano opatrunki alginianowe. Przed zmianami opatrunków wykonywanymi dwa razy dziennie, kończynę moczono w wodzie z szarym mydłem. Ponownie wykonano badanie bakteriologiczne i włączono empirycznie amoksycylinę z kwasem klawulanowym drogą doustną przez $10 \mathrm{dni}$. W badaniu bakteriologicznym stwierdzono Citrobacter freundii i Escherichia coli, a zmiany zapalne pomimo leczenia uległy gwałtownemu nasileniu, powodując wystąpienie ropowicy stopy. Stan ogólny chorego pogorszył się. Pacjent pogrążył się w apatii, wystąpiła hipotonia, nasiliła się niedokrwistość mikrocytarna, a temperatura ciała wzrosła do 38 stopni Celsjusza. Ze względu na stopień zaawansowania i progresję zmian, w ocenie autorki artykułu kończyna kwalifikowała się do amputacji na wysokości podudzia. Chory nie wyraził jednak zgody ani na hospitalizację, ani na leczenie operacyjne, twierdząc, że „chce umrzeć z własną kończyną" i prosił o pomoc w warunkach domowych. Dolegliwości bólowe ze strony stopy cukrzycowej oceniał na 7 w skali NRS. Klinicznie nie stwierdzano w jego przypadku dolegliwości charakterystycznych dla polineuropatii cukrzycowej.
Ze względu na konieczność transportu nie wykonano badania RTG stopy, a zmiany w ocenie klinicznej zakwalifikowano na 3. stopień zaawansowania [4]. Stwierdzono obecność rozległego, głębokiego owrzodzenia okolicy kostki przyśrodkowej i przyśrodkowej podeszwowej części stopy, drążącego do mięśni, ścięgien i stawów, ropnie całej okolicy podeszwowej, zaczerwienienie i zwiększone ucieplenie części grzbietowej stopy, podejrzewano również zapalenie kości. Wobec zaistniałej sytuacji, zgodnie z antybiogramem, włączono leczenie ceftriaksonem drogą dożylną przez $21 \mathrm{dni}$ i flukonazolem podawanym drogą doustną. Kontynuowano leczenie enoksaparyną, płukanie ropni oktenidyną z fenoksyetanolem na zmianę z jodopowidonem i gentamycyną oraz moczenie kończyny w wodzie z szarym mydłem. Ogniska martwicy usuwano, stosowano opatrunki alginianowe, a następnie opatrunki hydrowłókniste z jonami srebra. Stan ogólny chorego uległ poprawie. Dolegliwości bólowe zmniejszyły się do 2-3 w skali NRS i były akceptowane przez pacjenta po zastosowaniu poniższych leków:

- Fentanyl w plastrach w dawce $75 \mu \mathrm{g} / \mathrm{godz} .$, a następnie $50 \mu \mathrm{g} / \mathrm{godz}$;

- Gabapentyna w dawce 600 mg na dobę — większe dawki powodowały złe samopoczucie i nadmierną senność, chory nie tolerował pregabaliny z powodu zaburzeń świadomości;

- Amitryptylina $10 \mathrm{mg}$ rano, $20 \mathrm{mg}$ na noc;

- Lornoksykam 8 mg na dobę;

- Metamizol doraźnie w razie bólu 500-1000 mg na dobę;

- Klodronian 2 razy dziennie $400 \mathrm{mg}$ - większe dawki powodowały ból w nadbrzuszu.

W efekcie leczenia stan stopy uległ stabilizacji, jednak nadal występował obfity wyciek treści ropnej. W kontrolnym badaniu bakteriologicznym stwierdzono Enterococcus faecalis i włączono, zgodnie z antybiogramem, amoksycylinę z kwasem klawulanowym drogą dożylną przez 14 dni. Utrzymano leczenie miejscowe, usunięto tkanki martwicze. Po miesiącu powtórzono leczenie amoksycyliną z kwasem klawulanowym, ponieważ w kontrolnym badaniu bakteriologicznym utrzymywał się wzrost Enterococcus faecalis. Stan stopy uległ stopniowej poprawie.

Podczas uciążliwego leczenia w szóstym miesiącu opieki hospicyjnej stwierdzono u chorego półpasiec I gałęzi nerwu trójdzielnego lewego z zajęciem gałki ocznej. W obawie przed poważnymi powikłaniami ocznymi zaproponowano hospitalizację, na którą chory nie wyraził zgody i poprosił o leczenie w warunkach domowych. Włączono acyklowir drogą doustną w dawce 4 razy dziennie $800 \mathrm{mg}$ przez 14 dni pod ścisłą kontrolą nawodnienia i parametrów nerkowych, miejscowo stosowano acyklowir w maści do oczu 
6 razy na dobę na zmianę z dekspantenolem 2 razy na dobę przez 14 dni. Po konsultacji okulistycznej przeprowadzonej w domu w 10. dobie leczenia półpaśca, uzyskano informację, że nie ma ryzyka uszkodzenia gałki ocznej, utrzymywał się jedynie nieznaczny obrzęk powiek.

Na zmiany skórne czoła z towarzyszącą hiperalgezją skutecznie stosowano przez okres 21 dni maść z benzokainą, mentolem i tlenkiem cynku. Po ich wygojeniu, w obawie przed wystąpieniem neuralgii popółpaścowej, zaproponowano choremu blokady nerwu nadoczodołowego, na które nie wyraził zgody. Z przyczyn ekonomicznych nie stosowano lidokainy w plastrach.

Po zwiększeniu dawki fentanylu do $75 \mu \mathrm{g} / \mathrm{godz}$. dolegliwości bólowe chory oceniał jako akceptowalne (3-4 w skali NRS). W okresie 9 miesięcy od wystąpienia bólu spowodowanego półpaścem dolegliwości stopniowo ustąpiły. Zmniejszono dawkę fentanylu do $50 \mu \mathrm{g} / \mathrm{godz}$., a następnie do $25 \mu \mathrm{g} / \mathrm{godz}$., stopniowo odstawiono amitriptylinę. Po upływie kolejnych 5 miesięcy pojawił się świąd skóry w zakresie I gałęzi nerwu trójdzielnego, który ustąpił prawie całkowicie po ponownym włączeniu amitriptyliny w dawce 2 razy dziennie $10 \mathrm{mg}$.

W trakcie terapii półpaśca kontynuowano leczenie stopy cukrzycowej. Po 6 miesiącach opieki hospicyjnej stwierdzono w ranie stopy Enterobacter cloace i Pseudomonas aeruginosa. Zgodnie z wynikiem antybiogramu włączono ponownie leczenie ciprofloksacyną drogą doustną przez 10 dni z flukonazolem, kontynuowano także leczenie miejscowe.

Po 7 miesiącach obserwacji pojawiła się konieczność hospitalizacji pacjenta z powodu ostrych bólów brzucha. Pojawiły się wzdęcia, wymioty, gorączka do 38 stopni Celsjusza. Podejrzewano również zapalenie płuca prawego. Podczas leczenia szpitalnego stwierdzono także zakażenie układu moczowego wywołane Escherichia coli. Zgodnie z antybiogramem stosowano amoksycylinę z kwasem klawulanowym drogą doustną przez 10 dni. Podczas hospitalizacji nie odbyła się konsultacja dotycząca chirurgicznego opracowania stopy cukrzycowej.

Po zastosowanym leczeniu stan ogólny pacjenta uległ ponownie zdecydowanej poprawie i stabilizacji, dawka fentanylu wynosiła $50 \mu \mathrm{g} / \mathrm{godz}$., po 9 miesiącach leczenia stwierdzono całkowite wygojenie stopy. Natomiast po 14 miesiącach, pomimo bardzo dobrej opieki domowej, stwierdzono ropiejącą odleżynę pośladka lewego o wymiarach $5 \times 5 \mathrm{~cm}$. W badaniu bakteriologicznym uzyskano Klebsiella oxytoca, Proteus mirabilis i Pseudomonas aeruginosa. Równocześnie stwierdzono zakażenie układu moczowego wywołane Proteus mirabilis. Włączono amoksycylinę z kwasem klawulanowym drogą doustną przez 7 dni, następnie ze względu na infekcję układu moczowego, ciprofloksacynę również drogą doustną przez 14 dni. Miejscowo stosowano opatrunki z jonami srebra, po 2 miesiącach pielęgnacji odleżyna została wygojona.

Cewnik do pęcherza moczowego wymieniano regularnie - co 21 dni, kilkakrotnie podejmowano również nieskuteczne próby jego usunięcia. Okresowo stwierdzano zapalenie napletka, ustępujące po okładach z etakrydyny i oktenidyny z fenoksyetanolem. Po 16 miesiącach opieki hospicyjnej żona stwierdziła niedrożność cewnika, usunęła go zgodnie z instrukcją i pacjent zaczął oddawać mocz samoistnie. Początkowo nie współpracował i nie sygnalizował parcia na mocz, który oddawał do pampersa, co skutkowało zapaleniem napletka i wyprzeniami w pachwinach, kilkakrotnie leczonymi miejscowo etakrydyną i oktenidyną z fenoksyetanolem oraz sudokremem.

Chory cierpiał także na spastyczne zapalenie oskrzeli. Wystąpiło ono po 17 miesiącach opieki paliatywnej i leczone było ambulatoryjnie z pozytywnym efektem cefuroksymem drogą doustną przez 8 dni i fenoterolem z ipratropium w inhalacjach. Podczas każdej kolejnej antybiotykoterapii, która łącznie w okresie 22 miesięcy trwała około 142 dni, choremu podawano probiotyki. Od kwietnia 2017 roku pacjent nie otrzymywał antybiotyków. W sierpniu 2017 roku włączono amoksycylinę z kwasem klawulanowym drogą doustną z powodu zakażenia układu moczowego wywołanego Proteus mirabilis.

Podczas opieki kontynuowano zalecenia urologa, wartości PSA przez cały czas obserwacji utrzymywały się w granicach normy. W sierpniu 2017 roku wynik PSA wzrósł do 10,52 ng/ml. Po konsultacji urologa kontynuowano leczenie triptoreliną i dołączono bikalutamid, zalecono stopniowe odstawianie deksmetazonu. Obecnie ogólny stan pacjenta jest dobry. Jest on wydolny oddechowo i krążeniowo, ma dobry nastrój, poddawany jest systematycznej rehabilitacji, nie stwierdzono u niego klinicznych cech infekcji. Siada na łóżku do posiłków ze spuszczonymi nogami i na fotelu. Pomaga mu w tych czynnościach troskliwa żona. Dolegliwości bólowe ocenia na 1-2 w skali NRS. Obecne leczenie obejmuje fentanyl w plastrach w dawce $25 \mu \mathrm{g} / \mathrm{godz}$., gabapentynę $600 \mathrm{mg}$ na dobę, amitryptylinę $20 \mathrm{mg}$ na dobę i klodronian 800 mg na dobę.

\section{Omówienie}

Każdy pacjent ma prawo do ochrony zdrowia [5]. Prawa pacjenta o charakterze podmiotowym stanowią jego prawa indywidualne, zaś prawa społeczne dotyczą relacji pacjent-państwo. Problematyka dotycząca 
tych praw jest niezwykle istotna, zarówno dla pacjentów i osób bliskich, jak również lekarzy, pielęgniarek i innych pracowników ochrony zdrowia [1].

W polskim ustawodawstwie prawa pacjenta są zagwarantowane w:

1. Konstytucji Rzeczypospolitej Polskiej z dnia 2 kwietnia 1997 roku (Dz.U. z 1997 r. nr 78 poz. 483 z późn. zm.) - art. 68.1. [1, 5].

2. Ratyfikowanych umowach międzynarodowych:

- Karta Praw Pacjenta z 1984 roku wydana z inicjatywy Parlamentu Europejskiego Wspólnoty Europejskiej;

- Deklaracja Promocji Praw Pacjenta w Europie z 1994 roku;

- Europejska Karta Praw Pacjenta [6];

- Międzynarodowy Pakt Praw Obywatelskich i Politycznych ;

- Konwencja o Ochronie Praw Człowieka i Podstawowych Wolności [1].

3. Obowiązujących aktach prawnych, a zwłaszcza w Ustawie z dnia 6 listopada 2008 roku o prawach pacjenta i Rzeczniku Praw Pacjenta (tj. Dz.U. z 2017 r. poz. 1318 z późn. zm.).

Artykuły powyższej Ustawy gwarantują pacjentowi następujące prawa:

„Art. 16. Pacjent ma prawo do wyrażenia zgody na udzielenie określonych świadczeń zdrowotnych lub odmowy takiej zgody, po uzyskaniu informacji w zakresie określonym w art. 9.

Art. 17. 1. Pacjent, w tym małoletni, który ukończył 16 lat, ma prawo do wyrażenia zgody na przeprowadzenie badania lub udzielenie innych świadczeń zdrowotnych.

Art. 20. 1. Pacjent ma prawo do poszanowania intymności i godności, w szczególności w czasie udzielania mu świadczeń zdrowotnych.

2. Prawo do poszanowania godności obejmuje także prawo do umierania w spokoju i godności.

Art. 8. Pacjent ma prawo do świadczeń zdrowotnych udzielanych z należytą starannością przez podmioty udzielające świadczeń zdrowotnych w warunkach odpowiadających określonym w odrębnych przypisach wymaganiom fachowym i sanitarnym. Przy udzielaniu świadczeń zdrowotnych osoby wykonujące zawód medyczny kierują się zasadami etyki zawodowej określonymi przez właściwe samorządy zawodów medycznych" [2].

Ustawa z dnia 5 grudnia 1996 roku o zawodach lekarza i lekarza dentysty (Dz.U. z 2018 r. poz. 617 z póżn. zm.) w art. 30. gwarantuje pacjentowi prawo do obowiązkowego udzielania mu pomocy lekarskiej.

„Lekarz ma obowiązek udzielać pomocy lekarskiej w każdym przypadku, gdy zwłoka w jej udzieleniu mo- głaby spowodować niebezpieczeństwo utraty życia, ciężkiego uszkodzenia ciała lub ciężkiego rozstroju zdrowia oraz w innych przypadkach niecierpiących zwłoki" [3]

4. Aktach wykonawczych.

Na podstawie przytoczonych przepisów, regulujących autonomię pacjenta i obowiązki lekarza z tym związane, można stwierdzić, że prawdopodobnie nie naruszono prawa podczas procesu terapeutycznego opisanego chorego. Każdy etap opieki paliatywnej stanowi wyzwanie nie tylko dla pracowników hospicjum. Nieuleczalnie chory pacjent w najtrudniejszym okresie życia zmuszony jest do akceptacji swojej tragicznej sytuacji, a dodatkowo nieznanego dotychczas personelu medycznego. W przeciwnym razie nie może być mowy, zarówno o prawidłowej opiece, jak i o poprawie jakości życia chorych [7].

W Rozporządzeniu Ministra Zdrowia z dnia 29 października 2013 roku w sprawie świadczeń gwarantowanych z zakresu opieki paliatywnej i hospicyjnej (Dz.U. z 2018 r. poz. 742 z późn. zm.) świadczenia udzielane w warunkach domowych obejmują:

1. Świadczenia opieki zdrowotnej udzielane przez lekarzy, pielęgniarki, psychologów i fizjoterapeutów.

2. Leczenie bólu zgodne ze wskazaniami aktualnej wiedzy medycznej, za pomocą leków dostępnych na terytorium Rzeczypospolitej Polskiej.

3. Leczenie innych objawów somatycznych.

4. Opiekę psychologiczną nad świadczeniobiorcą i jego rodziną.

5. Rehabilitację.

6. Zapobieganie powikłaniom.

7. Bezpłatne wypożyczanie przez hospicja domowe wyrobów medycznych i środków pomocniczych (np. inhalatory, glukometry, wózki inwalidzkie, kule, sprzęt do pomiaru ciśnienia krwi).

8. Badania zlecone przez lekarza zatrudnionego w hospicjum domowym dla dorosłych lub dla dzieci do ukończenia 18. roku życia.

Świadczenia w zakresie domowej opieki paliatywnej (hospicjum domowego) udzielane są przy zachowaniu całodobowego dostępu do lekarza i pielęgniarki przez 7 dni w tygodniu, wizyt lekarza i pielęgniarki w zależności od potrzeb (odpowiednio nie rzadziej niż 2 razy miesiącu i 2 razy w tygodniu) [8]. Chorzy wymagają leczenia bólu i innych objawów i zapobiegania powikłaniom. Dotyczy to zwłaszcza stanów nagłych, związanych nie tylko z chorobą nowotworową, ale również z chorobami współistniejącymi. Wszystkie działania medyczne powinny być podejmowane na podstawie całościowej oceny klinicznej chorych uwzględniającej rokowanie, preferencje pacjentów oraz sytuację psychologiczną, socjalną i duchową chorych [9]. 
Niektóre poważne problemy zdrowotne muszą być rozwiązywane w trudnych warunkach, a w całym skomplikowanym procesie bardzo istotne są oczekiwania, postawy, stan fizyczny i psychiczny osób, sprawujących całodobową opiekę nad chorymi. Niezbędne jest zapewnienie zarówno choremu, jak i opiekunom wszechstronnej i fachowej pomocy, empatii i dostępności pracowników hospicjum domowego [10]. Opisany w artykule pacjent od początku sprawowania opieki jest pogodny i ufny. Na obecnym etapie choroby chce jednak przebywać w domu pod opieką bardzo troskliwej żony.

Mężczyzna dwukrotnie nie wyraził zgody na hospitalizację i proponowane leczenie. Jak wynika z uzasadnienia orzeczenia Sądu Najwyższego z dnia 27 października 2005 roku, pacjent ma prawo do odmowy leczenia: „prawo nie nakazuje pacjentowi poddawać się interwencji medycznej, a lekarzowi pokonywać oporu pacjenta, albo przez wykonywanie czynności, na które zgody nie wyraził lub którym się sprzeciwił, albo przez występowanie do sądu, aby taki sprzeciw pozbawił mocy". Nawet jeśli sprzeciw, czyli odmowa zgody na interwencję (bez względu na motywy: religijne, światopoglądowe, zdrowotne, wynikające z nadwrażliwości psychicznej pacjenta), wyrażona niewadliwie prowadzi do zaniechań dla pacjenta destrukcyjnych, z niebezpieczeństwem utraty życia włącznie, nie wolno stosować przymusu leczenia bez wyraźnej podstawy prawnej. Teoria przymusowej interwencji lekarskiej ze względu na „dobro" chorego została odrzucona. W orzeczeniu Sądu Najwyższego z dnia 21 grudnia 1971 roku (II CR 481/71, OSPiKA 1973 , z. 4, poz. 77) rozpatrywano sprawę powoda, który odmówił zgody na amputację nogi, a następnie domagał się odszkodowania, upatrując „winy” lekarza w tym, że uszanował jego wolę i nie podjął działania „jako prowadzący cudze sprawy bez zlecenia". Sąd Najwyższy słusznie uznał, że wola chorego w tym konkretnym stanie faktycznym nie była sprzeczna z ustawą ani z zasadami współżycia społecznego, co oznacza, że lekarz nie miał nie tylko obowiązku, ale i prawa do działania" [11].

Infekcje stóp u chorych na cukrzycę stanowią poważny problem, wymagający postępowania interdyscyplinarnego, ponieważ mogą być przyczyną amputacji kończyny [12]. Chorzy z głębokimi owrzodzeniami zgodnie z zaleceniami Polskiego Towarzystwa Diabetologicznego z 2017 roku wymagają leczenia szpitalnego, obejmującego również operacyjne opracowanie zmian. Domowe, nieinterdyscyplinarne leczenie stopy cukrzycowej w 3. stopniu zaawansowania u chorego w wieku podeszłym, z uogólnioną chorobą nowotworową, w ciężkim stanie ogólnym wydawało się być z góry skazane na niepowodzenie. Chociaż leczenie było długotrwałe (ok. 9 miesięcy), okazało się skuteczne dzięki zaangażowaniu i cierpliwości personelu medycznego, żony chorego, systematycznej zmianie opatrunków i celowanej antybiotykoterapii.

Wirus ospy wietrznej może ponownie ulec uaktywnieniu u osób o osłabionej odporności, wywołując półpasiec, zwłaszcza u chorych na nowotwory [13]. Lokalizacja w obrębie głowy jest związana z bardziej uporczywym i długotrwałym bólem [14]. W przypadku półpaśca I gałęzi nerwu trójdzielnego może dojść do uszkodzenia gałki ocznej. Nasz pacjent uniknął poważnych powikłań takich jak: zapalenie naczyń siatkówki, zapalenie tylnego odcinka błony naczyniowej i siatkówki, czy martwica siatkówki, nie doszło również do utraty wzroku [15]. Chory nie wyraził zgody na możliwe do wykonania w warunkach domowych blokady nerwu nadoczodołowego. Dolegliwości bólowe wywołane półpaścem i bóle kostne pacjent ocenia obecnie na 1-2 w skali NRS. Nie doszło w jego przypadku do ucisku struktur nerwowych [16].

Co wpłynęło na korzystne wyniki leczenia? Zapewne dobrej jakości zespołowa opieka zarówno ze strony personelu medycznego, jak i żony pacjenta. Prawdopodobnie korzystny wpływ miało również uszanowanie woli i praw pacjenta, a w konsekwencji wspólne podejmowanie decyzji dotyczących miejsca i sposobu leczenia $[17,18]$.

\section{Podsumowanie}

Rola domowej opieki paliatywnej jest we współczesnej medycynie niezwykle istotna. Podczas jej sprawowania często występują liczne bariery organizacyjne, psychiczne i ekonomiczne. Leczenie i niezbędna diagnostyka pacjentów w stanie ciężkim i w sytuacjach nagłych wymagają znacznych nakładów finansowych. Hospitalizacja może być pod tym względem korzystniejsza dla pacjenta, gdyż w szpitalu nie jest on obciążony kosztami leczenia, natomiast w hospicjach domowych część kosztów ponosi pacjent lub jego rodzina. Pomimo wielu problemów, często jednak udaje się udzielić chorym właściwej i skutecznej pomocy w domu.

Rozwaga lekarza, uszanowanie woli i przestrzeganie praw pacjenta, oraz wspólne podejmowanie decyzji dotyczących sposobu i miejsca leczenia są głęboko uzasadnione. Czy shared decision making może mieć korzystny wpływ na wyniki leczenia chorych objętych opieką paliatywną? Na przykładzie omawianego pacjenta wydaje się, że odpowiedź jest twierdząca. Problem ten wymaga jednak dalszych obserwacji i wnikliwych badań klinicznych. 


\section{Podziękowanie}

Serdecznie dziękuję pielęgniarce naszego hospicjum Zofii Ostrowskiej, dzięki której bezinteresownemu oddaniu dla pacjenta i niebywałej sumienności w wykonywaniu obowiązków, niemożliwe stało się realne. Dziękuję również najpiękniej jak potrafię pani Marii — żonie pana Jana, która pomimo problemów zdrowotnych i zmęczenia, jest zawsze gotowa do współpracy, uśmiechnięta i zadowolona z każdego „kroku naprzód".

\section{Piśmiennictwo}

1. Ozimek M, Prawa pacjenta - definicja i podstawy prawne. https://prezi.com/j5zoifbccq_8/prawa-pacjenta-definicja-i-podstawy-prawne/ (2017).

2. Ustawa $z$ dnia 6 listopada 2008 r. o prawach pacjenta i Rzeczniku Praw Pacjenta (Dz. U. z 2017 r. poz. 1318 z późń, zm.

3. Ustawa z dnia 5 grudnia 1996 r. o zawodach lekarza i lekarza dentysty. (Dz. U. z 2018 r. poz. 617 z późn zm.).

4. Czech A, Cypryk K, Czupryniak L, et al. Zalecenia kliniczne dotyczące postępowania u chorych na cukrzycę. Diagnostyka i leczenie zespołu stopy cukrzycowej. Diabetologia Praktyczna. Via Medica 2009; tom. ; 10(supl. A): A 23.

5. Konstytucja Rzeczypospolitej Polskiej z dnia 2 kwietnia 1997 r. (Dz U z 1997 r nr 78 poz 483 z późn zm.).

6. Prawa pacjenta w Polsce. http://www.kpk.nfz.gov. $\mathrm{pl} / \mathrm{pl} /$ leczenie-w-polsce-wynikajace-z-dyrektywy-transgranicznej-3/prawa-pacjenta-w-polsce.html NFZ. (2018).

7. Chojnacka-Szawłowska G, de Warden - Gałuszko K, Majkowicz M. Jakość życia w chorobie nowotworowej. Wydawnictwo Uniwersytetu Gdańskiego. ; 1994: 13-22.

8. Rozporządzenie Ministra Zdrowia z dnia 29 października 2013 r. w sprawie świadczeń gwarantowanych z zakre- su opieki paliatywnej i hospicyjnej. (Dz. U z 2018 r poz 742 z późn zm.).

9. Leppert W, Nosek K, Tomaszewski A. Stany nagłe u chorych na nowotwory w opiece paliatywnej. Piel. Zdr. Publ. 2015; 5. ; 1: 81-85.

10. Ossowski R, Sienkiewicz A. Dział specjalny: wybrane problemy opieki paliatywnej. Koncepcja wsparcia w opiece paliatywnej. Polskie Forum Psychologiczne 2007; tom 12: numer. ; 1: 5-21.

11. Świderska M. Prawo pacjenta do informacji, wyrażenia lub odmowy zgody na interwencję medyczną w świetle nowej ustawy o prawach pacjenta i Rzeczniku Praw Pacjenta znowelizowanej ustawy o zawodach lekarza i lekarza dentysty. Część II Materiały z Konferencji Naukowo-Szkoleniowej „Prawo do wyrażania zgody na zabieg medyczny i inne prawa pacjenta. ; 2009.

12. Korzon-Burakowska A, Tęcza S. Infekcje w przebiegu zespołu stopy cukrzycowej. Diabetologia Praktyczna. Via Medica 2005; tom 6. ; 2: 92-96.

13. Malec-Milewska M. Neuralgia popółpaścowa. Medycyna Paliatywna w Praktyce 2012; 6. ; 1: 28-37.

14. Przeklasa-Muszyńska A. Neuralgia popółpaścowa. Medycyna Bólu MCKPUJ Kraków. ; 2008: 1-6.

15. Mrukwa-Kominek E, Kawalec-Herbut E. Półpasiec ocznyaspekty kliniczne, objawy i leczenie. Magazyn lekarza Okulisty. 2011; 5(3): 156.

16. Mayzner-Zawadzka E. Leczenie przeciwbólowe chorych na raka stercza. Przegląd Urologiczny 2004; 2. ; 24: 19-22.

17. Elwyn G, Frosch D, Thomson R, et al. Shared decision making: a model for clinical practice. J Gen Intern Med. 2012; 27(10): 1361-1367, doi: 10.1007/s11606-012-2077$\underline{6}$, indexed in Pubmed: $\underline{22618581}$.

18. Heisler M, Bouknight RR, Hayward RA, et al. The relative importance of physician communication, participatory decision making, and patient understanding in diabetes self-management. J Gen Intern Med. 2002; 17(4): 243-252, indexed in Pubmed: 11972720. 